\title{
The Role of p16 and MDM2 Gene Polymorphisms in Prolactinoma: MDM2 Gene Polymorphisms May Be Associated with Tumor Shrinkage
}

\author{
SEDA TURGUT ${ }^{1}$, MUZAFFER ILHAN $^{2}$, SAIME TURAN $^{3}$, OZCAN KARAMAN $^{2}$, \\ ILHAN YAYLIM $^{3}$, OZLEM KUCUKHUSEYIN ${ }^{3}$ and ERTUGRUL TASAN ${ }^{2}$ \\ Departments of ${ }^{1}$ Internal Medicine, and ${ }^{2}$ Endocrinology and Metabolism, \\ Bezmialem Vakif University, Istanbul, Turkey; \\ ${ }^{3}$ Department of Molecular Medicine, The Institute of Experimental Medicine, \\ Istanbul University, Istanbul, Turkey
}

\begin{abstract}
Aim: Prolactinomas are thought to arise from clonal expansion of a single mutated cell which is subjected to growth stimuli of several permissive factors, although the pathogenetic mechanisms underlying tumorigenesis remain unclear. The present study aimed to investigate the role of p16 $(540 C \rightarrow G$ and $580 C \rightarrow T)$ and mouse double minute 2 $(M D M 2) \quad(S N P 309 T \rightarrow G)$ gene polymorphisms in tumorigenesis and characteristics of prolactinoma. Patients and Methods: A total of 74 patients with prolactinoma and 100 age- and gender-matched healthy individuals were enrolled in the study. Serum prolactin levels were measured by enzyme-linked immunosorbent assay (ELISA). p16 and MDM2 polymorphisms were determined by polymerase chain reaction-restriction fragment polymorphism and agarose gel electrophoresis. Results: p16 540C $\rightarrow$ G genotype distribution was found to be: CC: $66.2 \%, C G: 28.4 \%, G G$ : $5.4 \%$; p16 580C $\rightarrow$ T genotype distribution was found to be: CC: $82.4 \%, C T: 17.6 \%$, TT: $0 \%$ and MDM2 genotype distribution was found to be: TT: $31.1 \%, T G: 47.3 \%, G G$ : $21.6 \%$ in patients with prolactinoma. Tumor diameter before treatment was correlated with prolactin levels before treatment and percentage of prolactin decrease with treatment $(r=0.719, \quad p<0.001, \quad p=0.034 \quad r=0.256$, respectively). The number of patients with tumor size decrease of more than $50 \%$ in those with homozygous
\end{abstract}

This article is freely accessible online.

Correspondence to: Ozcan Karaman, MD, Bezmialem Vakif University, Department of Endocrinology and Metabolism, Vatan St., 34093, Istanbul, Turkey. Tel: +90 2124531700-7683, Fax: +90 2125336855, e-mail: ozcankaraman@hotmail.com

Key Words: Prolactinoma, p16, MDM2, polymorphism. genotype $(T T+G G)$ of $M D M 2 \quad S N P 309 T \rightarrow G$ was significantly higher than in heterozygous genotype (TG) carriers (odds ratio $(O R)=0.18, \quad 95 \% \quad$ confidence interval $(C I)=0.06-0.58 ; p=0.003)$. Conclusion: This study showed that p16 and MDM2 polymorphisms do not play a decisive role in tumorigenesis, but some genotypes of these polymorphisms might be associated with follow-up characteristics of prolactinoma.

Prolactinoma is the most frequent type of functional pituitary tumor, with an estimated prevalence of approximately 45 cases per 100,000 population in adults (1). The vast majority of prolactinomas are benign but may lead to significant morbidity associated with excessive hormone production and symptoms of mass effect (2). Prolactinomas are thought to arise from clonal expansion of a single mutated cell which is subjected to growth stimulation by several genetic and epigenetic factors. In particular, alteration in cell-cycle progression and regulating genes is expected to be critical in tumorigenesis, although the underlying molecular mechanisms remain unclear $(3,4)$. Because of the limited knowledge regarding their pathogenesis, recent studies focused on several molecular events in cell-cycle progression, cell survival, and protein synthesis in prolactinoma $(5,6)$.

Progression of cell proliferation and differentiation is mainly controlled by cyclin proteins, with their pattern of expression increasing and decreasing due to the stage of the cell cycle. Cyclin proteins bind to cyclin-dependent kinases (CDKs), which remain at a constant level during the cell cycle, and stimulate activation of cell-cycle progression. These cyclin and CDKs are characteristic for each phase of the cell cycle and are regulated by cyclin-dependent kinase inhibitors (CKI), which suppress formation of these compounds and inhibit cell proliferation (7). Tumorigenesis 
is thought to be caused by uncontrolled cell proliferation and delayed differentiation as a result of genetic alterations, polymorphisms and damage in CDK and CKI families (8).

p16 protein is a member of the CKI family, composed of 156 amino acids and encoded by p16 tumor suppressor gene (also known as CDKN2/INK4A) on chromosome 9p21 of the human genome. p16 gene products lead to blocking of $\mathrm{G}_{1} / \mathrm{S}$ transition by inhibiting the activity of CDK4, CDK6 and cyclin D1 complex which phosphorylates the retinoblastoma $(\mathrm{Rb})$ protein and precipitates the synthesis of transcription factors required for $\mathrm{S}$ phase. Therefore, inactivation of the pl6 gene increases cell proliferation and probably contributes to loss of growth control leading to tumorigenesis (9). Two polymorphisms of the $p 16$ gene, $540 \mathrm{C} \rightarrow \mathrm{G}(\mathrm{rs} 11515)$ and $580 \mathrm{C} \rightarrow \mathrm{T}(\mathrm{rs} 3088440)$ located in the 3'untranslated region (3'UTR) were recently identified (10). Several studies showed that these polymorphisms may play a crucial role in tumor development, prognosis and aggressiveness by affecting the function of p16 protein $(11,12)$.

Mouse double minute 2 (MDM2) gene, located in the 12q14.3-q15 chromosomal region, produces MDM2 protein. MDM2 binds to p53 tumor-suppressor protein and blocks its roles in cell-cycle arrest at the $G_{1}$ and $G_{2}$ checkpoints and apoptosis (13). Various modifications, that may occur in the p53 and MDM2 gene, can disrupt the interaction between these two gene products. It has been shown that the overexpression of MDM2 gene leads to cell-cycle arrest and apoptosis by increasing the degradation rate of $\mathrm{p} 53$ protein, and hence contributes to tumorigenesis (14). In addition, MDM2 overexpression is thought to be able to have a direct effect on tumorigenesis independently of the p53 pathway (15). As a single nucleotide polymorphism, the base pair change of a $\mathrm{G}$ to $\mathrm{T}$ at nucleotide 309 in the $M D M 2$ promoter region ( $r$ 2279744; SNP309T $\rightarrow \mathrm{G}$ ) alters the level of expression of MDM2 (16). It was reported that MDM2 $\mathrm{SNP309T} \rightarrow \mathrm{G}$ leads to loss of p53 tumor-suppressor activity and enhanced tumorigenesis in humans $(17,18)$.

Although previous studies determined the expression of p16 and MDM2 genes in pituitary tumors, as far as we are aware there is no study yet to investigate the association between these two gene polymorphisms and prolactinoma (19-21). The present study aimed to investigate the role of p16 $(540 \mathrm{C} \rightarrow \mathrm{G}$ and $580 \mathrm{C} \rightarrow \mathrm{T})$ and $M D M 2(\mathrm{SNP} 309 \mathrm{~T} \rightarrow \mathrm{G})$ gene polymorphisms in tumorigenesis and characteristics of prolactinoma. This study may contribute to the elucidation of tumorigenesis in order to understand the differences in tumor behavior, development of resistance to medical treatments and tumor recurrence after surgery for prolactinoma.

\section{Materials and Methods}

Study participants and prolactin assays. This prospective casecontrol study was performed at the Department of Endocrinology and Metabolism, Bezmialem Vakif University Hospital, Istanbul,
Table I. Baseline characteristics of prolactinoma patients and healthy controls.

Patients (n=74) Healthy controls $(n=100)$

\begin{tabular}{lcc}
\hline Age (years) & $35.4 \pm 11$ & $32.8 \pm 4.1$ \\
Gender $($ female/male) & $59 / 15$ & $78 / 22$ \\
BMI $\left(\mathrm{kg} / \mathrm{m}^{2}\right)^{*}$ & $26.5 \pm 5$ & $23.1 \pm 2$ \\
Prolactin $(\mathrm{ng} / \mathrm{ml}) *$ & $257.3 \pm 366.2$ & $13.6 \pm 4.9$ \\
Type of adenoma $(\mathrm{n}, \%)$ & & - \\
$\quad$ Microadenoma & $46(62.2)$ & - \\
$\quad$ Macroadenoma & $28(37.8)$ & - \\
Galactorrhea $(\mathrm{n}, \%)$ & $20(27)$ & - \\
Visual field defect $(\mathrm{n}, \%)$ & $2(2.7)$ & - \\
\hline
\end{tabular}

BMI: Body mass index. ${ }^{*} p<0.001$.

Turkey, between 2013 and 2014. Seventy-four patients with newly diagnosed prolactinoma (59 female and 15 male) and age- and gender-matched 100 healthy individuals ( 78 female and 22 male) were enrolled in this study. Age under 18 years, hyperprolactinemia as a result of other causes (e.g. chronic disease, medical treatment, other pituitary disease, pregnancy, and lactation) and having a history of operation or radiosurgery were exclusion criteria of the study. Patients were examined with hypophyseal magnetic resonance imaging (MRI) to explore the presence of an adenoma. Tumors were stratified according to the longest dimension as follows: microadenoma: $<1 \mathrm{~cm}$, macroadenoma: $\geq 1 \mathrm{~cm}$. To followup disease progression, clinical and laboratory examinations were repeated every 3 months and MRI was performed every 6 months. Patients received the treatment with cabergoline $(2 \times 0.25 \mathrm{mg} /$ week $)$ and the dose was adjusted to reach normalization of prolactin levels. Patients were considered to have responded to treatment if more than 50\% tumor shrinkage was achieved at the end of the first year.

Serum prolactin levels were measured by enzyme-linked immunosorbent assay (ELISA) with a commercial kit (DKO011-1; Diametra, Pozzuolo, Italy). Reference ranges for prolactin were: female: menstrual cycle 1.2-19.5 ng/ml; menopause $1.5-18.5 \mathrm{ng} / \mathrm{ml}$; male $1.8-17.0 \mathrm{ng} / \mathrm{ml}$.

All participants were volunteers, and their informed consent was obtained. This study was approved by the local Ethics Committee of Bezmialem Vakif University (Istanbul, Turkey) with 1/3 decision number on 08.01.2014 and all procedures were performed in accordance with guidelines established by the Declaration of Helsinki.

DNA isolation and genotyping. Blood samples $(10 \mathrm{ml})$ were obtained from each participant into EDTA tubes in order to $p 16$ and $M D M 2$ genotyping. DNA was extracted from whole blood using a salting-out technique (22). Genotyping analyzes were performed by polymerase chain reaction and restriction length polymorphism $(\mathrm{PCR}-\mathrm{RFLP})$ and defined $p 16(540 \mathrm{C} \rightarrow \mathrm{G}$ and $580 \mathrm{C} \rightarrow \mathrm{T})$ and $M D M 2$ $(\mathrm{SNP} 309 \mathrm{~T} \rightarrow \mathrm{G})$ polymorphisms. Primers used for PCR amplification were: $p 16540 \mathrm{C} \rightarrow \mathrm{G}$ and $\mathrm{p} 16580 \mathrm{C} \rightarrow \mathrm{T}$ : forward: 5 , GAT GTG CCA CAC ATC TTT GAC CT'3 and reverse: 5' CTA CGA AAG CGG GGT GGG TTG T’3; MDM2 SNP309 T $\rightarrow \mathrm{G}$ : forward: 5' CGC GGG AGT TCA GGG TAA AG'3 and reverse: 5' AGC TGG AGA CAA GTC AGG ACT TAA C'3. After PCR amplification of isolated genomic DNA with specific p16 and $M D M 2$ primer pairs, the SNP309T $\rightarrow \mathrm{G}$ substitution of $M D M 2$ gene 
Turgut et al: p16 and MDM2 Gene Polymorphisms in Prolactinoma

Table II. Clinical characteristics of patients with prolactinoma according to whether they had micro- or macroadenoma.

\begin{tabular}{|c|c|c|c|}
\hline & Microadenoma $(n=46)$ & Macroadenoma $(n=28)$ & $p$-Value \\
\hline Age (years) & $34.5 \pm 9.9$ & $36.6 \pm 13$ & NS \\
\hline Gender (female/male) & $41 / 5$ & $18 / 10$ & 0.016 \\
\hline BMI $\left(\mathrm{kg} / \mathrm{m}^{2}\right)$ & $25.9 \pm 4$ & $27.7 \pm 6.3$ & NS \\
\hline \multicolumn{4}{|l|}{ Prolactin (ng/ml) } \\
\hline Pre-treatment & $123.4 \pm 48.5$ & $470.6 \pm 531.3$ & $<0.0001$ \\
\hline Post-treatment & $6.9 \pm 7.3$ & $10.5 \pm 17.7$ & NS \\
\hline Reduction in prolactin level (\%) & $94 \pm 5.9$ & $96 \pm 6.2$ & NS \\
\hline \multicolumn{4}{|l|}{ Tumor diameter (mm) } \\
\hline Pre-treatment & $5.5 \pm 2.8$ & $18.6 \pm 10.9$ & $<0.0001$ \\
\hline Post-treatment & $3.1 \pm 2.6$ & $9.2 \pm 6.4$ & $<0.0001$ \\
\hline Reduction in tumor diameter $(\%)$ & $52.4 \pm 33.9$ & $51.2 \pm 31.1$ & NS \\
\hline Cabergoline dose (mg/week) & $1.0 \pm 0.4$ & $1.2 \pm 0.9$ & NS \\
\hline
\end{tabular}

BMI: Body mass index; NS: non-significant $(p>0.05)$.

and the $540 \mathrm{C} \rightarrow \mathrm{G}$ and $580 \mathrm{C} \rightarrow \mathrm{T}$ substitutions of the $p 16$ gene were identified by cutting the PCR products with appropriate restriction enzymes, MspA1I, MspI and HaeIII (MBI Fermentas, Ontario, Canada), respectively. The digested DNA fragments were run on $2 \%$ agarose gel followed by staining with ethidium bromide solution. The genotypes were determined under ultraviolet light.

Statistical analysis. Clinical parameters and demographic characteristics are expressed as mean $\pm \mathrm{SD}$, frequency, and the percentage. Statistical analysis was performed with Statistical Package for the Social Sciences (SPSS) software (version 20; IBM, SPSS Inc, NY, USA). Differences in the frequencies of alleles and polymorphisms between prolactinoma versus those of the control group were tested using the Chi-square statistic. Mann-Whitney $U$ and Kruskal-Wallis tests were used for comparing continuous variables depending on the number of the group. Student's $t$-test and ANOVA were applied if required. Spearman's correlation was used to assess the relationship between the two variables. The HardyWeinberg equilibrium was tested for all polymorphisms. The estimated odds ratios (OR) with $95 \%$ confidence interval (CI) were calculated for potential risk. Values were considered as statistically significant if the two-tailed $p$-value was less than 0.05 .

\section{Results}

Baseline characteristics of the patients with prolactinoma and healthy controls are shown in Table I. No significant difference was found in gender or age between patients and controls $(p>0.05)$. There were 59 female $(79.7 \%)$ and 15 male $(20.3 \%)$ patients with prolactinoma; 78 female $(78 \%)$ and 22 male (22\%) healthy controls in the study. The mean basal prolactin level was significantly higher in males $(451.8 \pm 462.9 \mathrm{ng} / \mathrm{ml})$ than in females $(215.8 \pm 337.8 \mathrm{ng} / \mathrm{ml})$ in the patient group $(p=0.036)$. There was no significant difference in prolactin levels according to gender in the healthy controls. Clinical characteristics of patients with prolactinoma according to micro- and macroadenomas are
Table III. Distribution of p16 $(540 C \rightarrow G$ and $580 C \rightarrow T)$ and mouse double minute 2 (MDM2) (SNP309T $\rightarrow G$ ) genotypes and alleles in prolactinoma patients and healthy controls.

\begin{tabular}{lccl}
\hline Genotype/allele & $\begin{array}{c}\text { Prolactinoma, } \\
\text { n } \%)\end{array}$ & $\begin{array}{c}\text { Healthy controls, } \\
\mathrm{n}(\%)\end{array}$ & $p$-Value \\
\hline p16 540C $\rightarrow \mathrm{G}$ & & & $>0.05$ \\
CC & $49(66.2)$ & $57(57)$ & \\
CG & $21(28.4)$ & $38(38)$ & \\
GG & $4(5.4)$ & $5(5)$ & \\
C & $119(80.4)$ & $152(76)$ & \\
G & $29(19.6)$ & $48(24)$ & $>0.05$ \\
p16 580C $\rightarrow$ T & & & \\
CC & $61(82.4)$ & $85(85)$ & \\
CT & $13(17.6)$ & $13(13)$ & \\
TT & $0(0)$ & $2(2)$ & \\
C & $135(91.2)$ & $183(91.5)$ & \\
T & $13(8.8)$ & $17(8.5)$ & \\
MDM2 SNP309T $\rightarrow$ G & & & \\
TT & $23(31.1)$ & $25(25)$ & \\
TG & $35(47.3)$ & $50(50)$ & \\
GG & $16(21.6)$ & $25(25)$ & \\
T & $81(54.7)$ & $100(50)$ & \\
G & $67(45.3)$ & $100(50)$ & \\
\hline
\end{tabular}

given in Table II. Macroadenoma frequency was significantly higher in male patients than in females $(\mathrm{OR}=4.55,95 \%$ $\mathrm{CI}=1.36-15.25 ; p=0.016$ ).

Percentage of reduction in prolactin level was moderately correlated with pre-treatment prolactin level $(\mathrm{r}=0.279$, $p=0.019)$, negatively well-correlated with post-treatment prolactin level $(\mathrm{r}=-0.732, p<0.001)$. Pre-treatment tumor diameter was correlated with pre-treatment prolactin and percentage of reduction in prolactin level $(\mathrm{r}=0.719, p<0.001$; 
Table IV. The comparisons of characteristics among the p16 $(540 C \rightarrow G$ and $580 C \rightarrow T)$ and mouse double minute 2 (MDM2) (SNP309T $\rightarrow G)$ genotypes in patients with prolactinoma. Data are shown as mean $\pm S D$.

\begin{tabular}{|c|c|c|c|c|c|c|c|c|c|c|}
\hline \multirow[t]{2}{*}{ Genotype } & \multirow{2}{*}{$\begin{array}{l}\text { Age } \\
\text { (years) }\end{array}$} & \multirow{2}{*}{$\begin{array}{c}\text { Gender } \\
(\mathrm{f} / \mathrm{m})\end{array}$} & \multicolumn{3}{|c|}{ Prolactin $(\mathrm{ng} / \mathrm{ml})$} & \multicolumn{2}{|c|}{ Tumor diameter $(\mathrm{mm})$} & \multicolumn{2}{|c|}{$\begin{array}{l}\text { Reduction in tumor } \\
\text { diameter } \mathrm{n}(\%)\end{array}$} & \multirow{2}{*}{$\begin{array}{c}\text { Cabergoline } \\
\text { dose } \\
\text { (mg/week) }\end{array}$} \\
\hline & & & $\begin{array}{c}\text { Pre- } \\
\text { treatment }\end{array}$ & $\begin{array}{l}\text { Post- } \\
\text { treatment }\end{array}$ & $\begin{array}{c}\text { Reduction in } \\
\text { prolactin level (\%) }\end{array}$ & $\begin{array}{c}\text { Pre- } \\
\text { treatment }\end{array}$ & $\begin{array}{l}\text { Post- } \\
\text { treatment }\end{array}$ & $<50 \%$ & $\geq 50 \%$ & \\
\hline \multicolumn{11}{|c|}{ p16 $540 \mathrm{C} \rightarrow \mathrm{G}$} \\
\hline $\mathrm{CC}$ & $33.7 \pm 1.4$ & $42 / 7$ & $254 \pm 393.3$ & $9.3 \pm 14.7$ & $94.5 \pm 6.3$ & $10.2 \pm 9.4$ & $5.5 \pm 5.4$ & $13(32.5)$ & $27(67.5)$ & $1.1 \pm 0.7$ \\
\hline CG & $39.1 \pm 2.7$ & $17 / 4$ & $212.8 \pm 293.2$ & $7.1 \pm 7.5$ & $94.5 \pm 5.9$ & $9.1 \pm 5.5$ & $5.2 \pm 4.7$ & $9(45)$ & $11(55)$ & $1 \pm 0.3$ \\
\hline GG & $34.3 \pm 9.6$ & $2 / 2$ & $549.6 \pm 435.4$ & $3.7 \pm 2.6$ & $98.8 \pm 6.1$ & $22.5 \pm 19.6$ & $6.3 \pm 9.5$ & $0(0)$ & $4(100)$ & $1.1 \pm 0.6$ \\
\hline \multicolumn{11}{|c|}{$\mathrm{p} 16580 \mathrm{C} \rightarrow \mathrm{T}$} \\
\hline $\mathrm{CC}$ & $35.9 \pm 1.4$ & $52 / 9$ & $260.2 \pm 379.2$ & $8.5 \pm 13.4$ & $95.0 \pm 6.0$ & $10.7 \pm 9.8$ & $5.4 \pm 5.3$ & $18(34)$ & $35(66)$ & $1.1 \pm 0.7$ \\
\hline $\mathrm{CT}$ & $32.6 \pm 3.2$ & $9 / 4$ & $248.6 \pm 340.4$ & $7.7 \pm 6.2$ & $93.4 \pm 6.4$ & $10.0 \pm 8.8$ & $5.9 \pm 5.9$ & $4(36.4)$ & $7(63.6)$ & $1.0 \pm 0.3$ \\
\hline TT & - & - & - & - & - & - & - & - & - & - \\
\hline \multicolumn{11}{|c|}{ MDM2 SNP309T $\rightarrow$ G } \\
\hline TT & $33.4 \pm 1.9$ & $20 / 3$ & $260.9 \pm 336.3$ & $6.4 \pm 7.1$ & $94.7 \pm 6.6$ & $10.7 \pm 11.2$ & $4.0 \pm 4.7$ & $3(15)$ & $17(85)$ & $1.0 \pm 0.6$ \\
\hline TG & $35.1 \pm 2.0$ & $28 / 7$ & $296.3 \pm 451.8$ & $10.4 \pm 16.8$ & $94.9 \pm 6.1$ & $10.9 \pm 10.0$ & $6.8 \pm 5.7$ & $16(53.3)$ & $14 *(46.7)$ & $1.2 \pm 0.7$ \\
\hline GG & $38.5 \pm 3.0$ & $13 / 3$ & $174.6 \pm 185.0$ & $6.4 \pm 5.2$ & $94.7 \pm 5.7$ & $9.7 \pm 5.5$ & $4.6 \pm 4.9$ & $3(21.4)$ & $11(78.6)$ & $1.0 \pm 0.2$ \\
\hline
\end{tabular}

$\mathrm{f} / \mathrm{m}:$ Female/male. $* \mathrm{TT}+\mathrm{GG}$ vs. TG: Odds ratio $=0.18,95 \%$ confidence interval $=0.06-0.58, p=0.003$.

and $\mathrm{r}=0.256, p=0.034$; respectively). Post-treatment tumor diameter was well-correlated with pre-treatment prolactin level and pre-treatment tumor diameter $(\mathrm{r}=0.569, p<0.001$; and $\mathrm{r}=0.638, p<0.001$; respectively). The mean cabergoline dose was also moderately correlated with the post-treatment prolactin level and pre-treatment tumor diameter $(\mathrm{r}=0.443$, $p<0.001$; and $\mathrm{r}=0.284, p=0.017$; respectively).

The distribution of $p 16(540 \mathrm{C} \rightarrow \mathrm{G}$ and $580 \mathrm{C} \rightarrow \mathrm{T})$ and $M D M 2$ $(\mathrm{SNP} 309 \mathrm{~T} \rightarrow \mathrm{G})$ genotypes and alleles in prolactinoma patients and healthy subjects is shown in Table III. Genotype distributions of $p 16(540 \mathrm{C} \rightarrow \mathrm{G}$ and $580 \mathrm{C} \rightarrow \mathrm{T})$ and $M D M 2$ $(\mathrm{SNP} 309 \mathrm{~T} \rightarrow \mathrm{G})$ polymorphisms were in agreement with the Hardy-Weinberg equilibrium both in control and patient groups ( $p>0.05)$. CC genotype (homozygous wild-type) frequency was higher, without statistical significance, for both $p 16540 \mathrm{C} \rightarrow \mathrm{G}$ and p16 580C $\rightarrow \mathrm{T}$ polymorphisms among patients with prolactinoma. The comparisons of characteristics among the p16 and MDM2 genotypes in patients with prolactinoma are summarized in Table IV. The number of patients with tumor diameter decreased more than $50 \%$ in homozygous genotype (TT+GG) carriers of $M D M 2 \mathrm{SNP} 309 \mathrm{~T} \rightarrow \mathrm{G}$ is significantly higher than in heterozygous genotype $(\mathrm{TG})$ carriers $(\mathrm{OR}=0.18$, 95\% CI=0.06-0.58; $p=0.003$ ). However, other than that, no significant association was found between characteristics of prolactinoma and p16, MDM2 gene polymorphisms and alleles.

\section{Discussion}

Although prolactinoma is the most frequent hypophyseal tumor, our knowledge regarding the molecular events that occur during lactotroph cell proliferation is limited.
Molecular studies have been performed on more atypical prolactinomas due to surgical removal of prolactinoma is rarely performed compared to other types of pituitary tumors (23). As a consequence, factors related to tumor development and clinical parameters are not clearly understood even if previous studies have investigated cellular mechanisms involving tumor pathogenesis. In our study, we evaluated polymorphisms in the p16 and MDM2 gene and their role in tumorigenesis and clinical characteristics of prolactinoma.

The $p 16$ gene is an important tumor-suppressor gene that functions in the negative regulation of $G_{1} / S$ transition of the cell cycle (24). Several studies have shown that deletion, promoter hypermethylation, or loss of heterozygosity and homozygosity at the $9 \mathrm{p} 21$ chromosome area (coding $p 16^{I N K 4 A} / p 14^{A R F} / p 15$ tumor-suppressor loci) result in loss of pl6 expression $(25,26)$. The demonstration of increased $\mathrm{p} 16$ expression in differentiated adult human brain tissue suggests a role for p16 in the development of human brain and possibly in tumor pathogenesis (27). It has been shown that the presence of mutational changes of p16 gene in several intracranial tumors such as anaplastic astrocytoma, glioblastoma, and pituitary adenoma (28-30). Seamann et al. detected $p 16^{I N K 4 a}$ gene alterations in hypophyseal adenomas, and they reported that p16 down-regulation is one of the most important mechanisms involving somatotropic and corticotropic adenomas. The same study revealed that $C D K N 2 A / p 16$ inactivation was associated with tumor type and size and that pl6 down-regulation was observed during the progression of adenoma rather than the onset of tumor development (31). A similar study found a significant association between $p 16^{I N K 4 a}$ 
methylation and tumor size. The authors suggested that $p 16$ inactivation may be important in development, progression, and behavior of hypophyseal tumors (32). The $540 \mathrm{C} \rightarrow \mathrm{G}$ $(\mathrm{rs}=11515)$ and $580 \mathrm{C} \rightarrow \mathrm{T}(\mathrm{rs}=3088440)$ polymorphisms that are present in the 3'UTR region of the p16 gene can lead to tumor development by altering several cellular pathways. One study from Turkey found that $\mathrm{C}$ allelic frequency in $p 16$ $540 \mathrm{C} \rightarrow \mathrm{G}$ polymorphism was $77.4 \%$ and the $\mathrm{G}$ allelic frequency was $22.6 \%$ (21). Similar to allelic frequencies in $p 16$ $540 \mathrm{C} \rightarrow \mathrm{G}$ polymorphism that has been shown in a European population (http://www.ensembl.org/Homo_sapiens/Variation/ Population?db=core;r=9:21967700-21968700; v=rs11515; $\mathrm{vdb}=$ variation; $\mathrm{vf}=22717$ ), we found the $\mathrm{C}$ allelic frequency of $76 \%$ and $\mathrm{G}$ allelic frequency of $24 \%$ in our study. In addition, the $\mathrm{C}$ allelic frequency in $p 16580 \mathrm{C} \rightarrow \mathrm{T}$ polymorphism was $91.5 \%$, and the $\mathrm{T}$ allelic frequency was $8.5 \%$. These rates are also consistent with the rates shown in a European population (http://www.ensembl.org/Homo_sapiens/Variation/Population? $\mathrm{db}=$ core; $\mathrm{r}=9: 21967660-21968660 ; \mathrm{v}=\mathrm{rs} 3088440 ; \mathrm{vdb}=\mathrm{variation}$; $\mathrm{vf}=2689541)$. Tuna et al. investigated the role of $p 16$ $(540 \mathrm{C} \rightarrow \mathrm{G}$ and $\mathrm{p} 16580 \mathrm{C} \rightarrow \mathrm{T})$ and MDM2 $(\mathrm{SNP} 309 \mathrm{~T} \rightarrow \mathrm{G})$ polymorphisms in development and progression of colorectal cancer. They found a significant difference between patient and control groups regarding the distribution of pl6 $540 \mathrm{C} \rightarrow \mathrm{G}$ polymorphism (12). Another study by Cander et al. involving patients with prolactinoma, did not find an association between p16 540C $\rightarrow$ G polymorphism and tumor behavior. However, they recorded a higher frequency of $\mathrm{CG}$ genotype among patients with giant prolactinoma and patients with increased Ki67 index, which is an indicator of high proliferative capacity, although this did not reach a level of statistical significance (21). Consistent with their results, p16 540C $\rightarrow \mathrm{G}$ polymorphism had a similar distribution across patient and control groups in our study. In contrast to their findings, the patient group with macroadenoma had a higher frequency of CC genotype, which is the homozygous wild-type for both $p 16$ $540 \mathrm{C} \rightarrow \mathrm{G}$ and $\mathrm{p} 16580 \mathrm{C} \rightarrow \mathrm{T}$ polymorphisms in our study. However, the difference did not reach statistical significance. Further larger scale studies are needed to explain the results regarding the significance of this difference.

The potential of MDM2 gene in tumorigenesis has been determined by demonstration of causes of overexpression in human tumors, such as gene amplification, increased transcription, and translation (33). It was thought that factors that can induce cellular stress, such as cytokines and growth factors, which are known to play a role in the pathogenesis of hypophyseal tumors, may contribute to tumor development via acting on p53 and MDM2 pathways. Based on this hypothesis, MDM2 protein expression in hypophyseal tumors was first demonstrated in a study by Suliman et al. (19). Although p53 is one of the most frequently inactivated genes in human cancer, $p 53$ mutation was very rarely detected in hypophyseal adenomas $(34,35)$. As a possible explanation for this, it was suggested that in the pathogenesis of hypophyseal tumors, the effect of cellular stress on p53 pathway could be more important than mutations in p53 and that p53 may not initiate tumor development, but could play a role in prognosis (36). The $\mathrm{T} \rightarrow \mathrm{G}$ base exchange occurring at 309th nucleotide of the first intron of $M D M 2$ gene is expressed as $M D M 2$ $\mathrm{SNP309T} \rightarrow \mathrm{G}$ ( $\mathrm{rs}=\mathrm{rs} 2279744)$, and this mutation causes an increased level of MDM2 protein, leading to suppression of p53 apoptosis pathway (18). One study from Turkey found the $\mathrm{T}$ allelic frequency of $M D M 2$ polymorphism to be $44.7 \%$, and the $\mathrm{G}$ allelic frequency $55.3 \%$ (12). Similarly, in our study, we found a $\mathrm{T}$ allelic frequency of $50 \%$ and $\mathrm{G}$ allelic frequency of $50 \%$. In a European population, the $\mathrm{T}$ allelic frequency was found to be $64 \%$ and that of the $\mathrm{G}$ allele was found to be $36 \%$. Conversely, the $\mathrm{T}$ allelic frequency was found to be $43 \%$ and $\mathrm{G}$ allelic frequency $57 \%$ in an Asian population (http://www.ensembl.org/Homo_sapiens/Variation/Population? $\mathrm{r}=12: 68808300-68809300 ; \mathrm{v}=\mathrm{rs} 2279744 ; \quad \mathrm{vdb}=$ variation; $\mathrm{vf}=1937624)$. There are several studies that investigated the effect of the MDM2 polymorphism on cancer development risk and prognosis. A large-scale study by Schmidt et al. did not show any association between $M D M 2 \mathrm{SNP} 309 \mathrm{~T} \rightarrow \mathrm{G}$ and p53 polymorphisms and breast cancer, whereas another study found a strong relationship between $M D M 2$ SNP309T $\rightarrow \mathrm{G}$ polymorphism and survival in patients with breast cancer (37, 38). A study by Hirata et al. involving patients with renal cell carcinoma showed that $M D M 2$ polymorphism was associated with increased renal cell carcinoma risk. The same study reported that MDM2 GG genotype was significantly more frequent compared to TT or TG genotypes in renal cancer tissues (39). In their study, Hori et al. did not find a significant difference between the patient group with pancreatic ductal adenocarcinoma and chronic pancreatitis and healthy volunteers regarding $M D M 2$ polymorphism. However, they found patients with $M D M 2$ GG genotype had shorter total life expectancy compared to those with other (TG, TT) genotypes (40). Another study by Chua et al. reported $M D M 2$ TT genotype was associated with lung cancer in non-smoking women in a Chinese population (41). A similar study in the same population showed the $G$ allele was associated with increased risk of cancer; however, early age of onset was found to be associated with the TT genotype (42).

Several points draw attention as the cause of these differences in genotype distribution in terms of disease development risk and prognosis. Regarding MDM2 polymorphism, the basal $\mathrm{T}$ allelic frequency was found to be higher in a European population, while the basal $G$ allelic frequency was found to be high in an Asian population. This suggests possible ethnic differences in cancer risk determined by $M D M 2$ gene functions and alleles. These ethnic differences are possibly among the causes of the differences in activity of individual polymorphic variants of the genes present in the 
p53 pathway. In our study, we did not find a significant difference between the prolactinoma and control groups regarding $M D M 2$ polymorphism. When we examined the relationship of genotypes with clinical parameters, we found that the number of patients with greater than $50 \%$ reduction in tumor size was significantly higher among those carrying homozygous genotypes (TT+GG) in comparison to those with heterozygous $(\mathrm{TG})$ genotype $(\mathrm{OR}=0.18,95 \% \mathrm{CI}=0.06-0.58$, $p=0.003$ ). This result indicates a better response to treatment in patients with a homozygous genotype in comparison to those with a heterozygous genotype. Similarly to what was mentioned about previous population studies, ethnic differences may be responsible for this result. Another important point was the possible confounding effect in polymorphism studies caused by susceptibility of $\mathrm{p} 53$ control over cell proliferation to environmental factors. Recent evidence indicates cellular stress factors that could lead to genotoxic injuries such as cytokines, growth factors, hypoxia, and metabolic alterations. These may be effective at the initial phase of p53 response and may cause differences in functionality of polymorphisms (43).

Current single nucleotide polymorphism studies give enlightening results that would aid in the determination of tumor prevalence in the population, the age of tumor incidence, and response of these tumors to treatment. According to our results, while there was no association of p16 and MDM2 gene polymorphisms with prolactinoma development, it was shown that carrying homozygous genotype (TT+GG) of MDM2 SNP309T $\rightarrow \mathrm{G}$ might be associated with tumor shrinkage in patients with prolactinoma. We hope that our results contribute to shedding light on future studies for a better understanding of tumor etiopathogenesis, which is essential to elucidate the distinguishing differences in tumor behavior, to identify new prognostic parameters, and to develop effective treatment options.

\section{Conflicts of Interest}

The Authors declare that they have no conflict of interest in regard to this study.

\section{Acknowledgements}

This study was supported by Bezmialem Vakif University Council of Research (12.2013/20). The Authors would also like to thank their colleague Dr. Omur Tastan for her support at every step of the study process.

\section{References}

1 Fernandez A, Karavitaki N and Wass JA: Prevalence of pituitary adenomas: A community-based, cross-sectional study in Banbury (Oxfordshire, UK). Clin Endocrinol 72(3): 377-382, 2010.

2 Colao A: Pituitary tumours: The prolactinoma. Best Pract Res Clin Endocrinol Metab 23(5): 575-596, 2009.
3 Melmed S: Mechanisms for pituitary tumorigenesis: The plastic pituitary. J Clin Invest 112(11): 1603-1618, 2003.

4 Dworakowska D and Grossman AB: The pathophysiology of pituitary adenomas. Best Pract Res Clin Endocrinol Metab 23(5): 525-541, 2009.

5 Tong Y, Zheng Y, Zhou J, Oyesiku NM, Koeffler HP and Melmed S: Genomic characterization of human and rat prolactinomas. Endocrinology 153(8): 3679-3691, 2012.

6 Zhao L, Lin $M$ and Wang S: Identification of human prolactinoma related genes by DNA microarray. J Cancer Res Ther 10(3): 544-548, 2014.

7 Agarwal P, Sandey M, DeInnocentes P and Bird RC: Tumorsuppressor gene P16/INK4A/CDKN2A-dependent regulation into and out of the cell cycle in a spontaneous canine model of breast cancer. J Cell Biochem 114(6): 1355-1363, 2013.

8 Hartwell LH and Kastan MB: Cell cycle control and cancer. Science 266(5192): 1821-1828, 1994.

9 Serrano M, Hannon GJ and Beach D: A new regulatory motif in cell-cycle control causing specific inhibition of cyclin d/CDK4. Nature 366(6456): 704-707, 1993.

10 Fombonne J, Devouassoux-Shisheboran M, Bouvier R, Droz JP, Benahmed $\mathrm{M}$ and Krantic S: Analysis of P16INK4A gene promoter in male germ-cell tumors: Identification of a new point mutation. Cancer Detect Prev 29(1): 1-7, 2005.

11 McCloud JM, Sivakumar R, Greenhough A, Elder J, Jones PW, Deakin M, Elder JB, Fryer AA and Hoban PR: P16INK4A polymorphism: Associations with tumour progression in patients with sporadic colorectal cancer. Int J Oncol 25(5): 1447-1452, 2004.

12 Tuna G, Kucukhuseyin O, Arikan S, Kaytan Saglam E, Guler E, Cacina C, Oztop O, Turan S, Korkmaz G and Yaylim I: Do $C D K N 2$ P16 $540 \mathrm{C}>\mathrm{G}, C D K N 2$ p16 $580 \mathrm{C}>\mathrm{T}$, and $M D M 2$ SNP309 T>G gene variants act on colorectal cancer development or progression? DNA Cell Biol 32(7): 400-408, 2013.

13 Mitchell EL, White GR, Santibanez-Koref MF, Varley JM and Heighway J: Mapping of gene loci in the q13-q15 region of chromosome 12. Chromosome Res 3(4): 261-262, 1995.

14 Freedman DA and Levine AJ: Regulation of the p53 protein by the MDM2 oncoprotein--thirty-eighth G.H.A. Clowes Memorial Award Lecture. Cancer Res 59(1): 1-7, 1999.

15 Oliner JD, Kinzler KW, Meltzer PS, George DL and Vogelstein $\mathrm{B}$ : Amplification of a gene encoding a p53-associated protein in human sarcomas. Nature 358(6381): 80-83, 1992.

16 Grochola LF, Zeron-Medina J, Meriaux S and Bond GL: Singlenucleotide polymorphisms in the p53 signaling pathway. Cold Spring Harb Perspect Biol 2(5): a001032, 2010.

17 Knappskog S and Lonning PE: Mdm2 promoter snp285 and snp309; phylogeny and impact on cancer risk. Oncotarget 2(3): 251-258, 2011.

18 Bond GL, Hu W, Bond EE, Robins H, Lutzker SG, Arva NC, Bargonetti J, Bartel F, Taubert H, Wuerl P, Onel K, Yip L, Hwang SJ, Strong LC, Lozano G and Levine AJ: A single nucleotide polymorphism in the MDM2 promoter attenuates the p53 tumor-suppressor pathway and accelerates tumor formation in humans. Cell 119(5): 591-602, 2004.

19 Suliman M, Royds J, Cullen D, Timperley W, Powell T, Battersby $\mathrm{R}$ and Jones TH: MDM2 and the p53 pathway in human pituitary adenomas. Clin Endocrinol 54(3): 317-325, 2001.

20 Aflorei ED and Korbonits M: Epidemiology and etiopathogenesis of pituitary adenomas. J Neurooncol 117(3): 379-394, 2014. 
21 Cander S, Karkucak M, Gul OO, Sag SO, Yakut T, Ersoy C, Tuncel E and Erturk E: Association between p16(CDKN2A) C540G polymorphism and tumor behavior in prolactinoma: A single-center study. Biomed Rep 2(4): 589-595, 2014.

22 Miller SA, Dykes DD and Polesky HF: A simple salting-out procedure for extracting DNA from human nucleated cells. Nucleic Acids Res 16(3): 1215, 1988.

23 Casanueva FF, Molitch ME, Schlechte JA, Abs R, Bonert V, Bronstein MD, Brue T, Cappabianca P, Colao A, Fahlbusch R, Fideleff H, Hadani M, Kelly P, Kleinberg D, Laws E, Marek J, Scanlon M, Sobrinho LG, Wass JA and Giustina A: Guidelines of the pituitary society for the diagnosis and management of prolactinomas. Clin Endocrinol 65(2): 265-273, 2006.

24 Baylin SB, Herman JG, Graff JR, Vertino PM and Issa JP: Alterations in DNA methylation: A fundamental aspect of neoplasia. Adv Cancer Res 72: 141-196, 1998.

$25 \mathrm{Kamb}$ A, Gruis NA, Weaver-Feldhaus J, Liu Q, Harshman K, Tavtigian SV, Stockert E, Day RS, 3rd, Johnson BE and Skolnick MH: A cell-cycle regulator potentially involved in genesis of many tumor types. Science 264(5157): 436-440, 1994.

26 Ranade K, Hussussian CJ, Sikorski RS, Varmus HE, Goldstein AM, Tucker MA, Serrano M, Hannon GJ, Beach D and Dracopoli NC: Mutations associated with familial melanoma impair p16 INK4 function. Nat Genet 10(1): 114-116, 1995.

27 Lois AF, Cooper LT, Geng Y, Nobori T and Carson D: Expression of the p16 and p15 cyclin-dependent kinase inhibitors in lymphocyte activation and neuronal differentiation. Cancer Res 55(18): 4010-4013, 1995.

28 Biernat W, Tohma Y, Yonekawa Y, Kleihues P and Ohgaki H: Alterations of cell cycle regulatory genes in primary (de novo) and secondary glioblastomas. Acta Neuropathol 94(4): 303-309, 1997.

29 Heaney AP and Melmed S: New pituitary oncogenes. Endocr Relat Cancer 7(1): 3-15, 2000.

30 Ono Y, Tamiya T, Ichikawa T, Kunishio K, Matsumoto K, Furuta $\mathrm{T}$, Ohmoto T, Ueki $\mathrm{K}$ and Louis DN: Malignant astrocytomas with homozygous $C D K N 2 / P 16$ gene deletions have higher $\mathrm{Ki}$ 67 proliferation indices. J Neuropathol Exp Neurol 55(10): 1026-1031, 1996.

31 Seemann N, Kuhn D, Wrocklage C, Keyvani K, Hackl W, Buchfelder M, Fahlbusch R and Paulus W: CDKN2A/P16 inactivation is related to pituitary adenoma type and size. $\mathrm{J}$ Pathol 193(4): 491-497, 2001

32 Abd El-Moneim HM and Abd El-Rehim D: Immunohistochemical and molecular study of $p 16^{I N K 4 A}$ expression in pituitary adenoma. J Egypt Natl Canc Inst 21(4): 351-360, 2009.

33 Geddert H, Kiel S, Zotz RB, Zhang J, Willers R, Gabbert HE and Sarbia M: Polymorphism of p16 INK4A and cyclin D1 in adenocarcinomas of the upper gastrointestinal tract. J Cancer Res Clin Oncol 131(12): 803-808, 2005.
34 Landers JE, Haines DS, Strauss JF, 3rd and George DL: Enhanced translation: A novel mechanism of $M D M 2$ oncogene overexpression identified in human tumor cells. Oncogene 9(9): 2745-2750, 1994.

35 Tanizaki Y, Jin L, Scheithauer BW, Kovacs K, Roncaroli F and Lloyd RV: P53 gene mutations in pituitary carcinomas. Endocr Pathol 18(4): 217-222, 2007.

36 Levy A, Hall L, Yeudall WA and Lightman SL: P53 gene mutations in pituitary adenomas: Rare events. Clin Endocrinol 41(6): 809-814, 1994

37 Zhou Y, Zhang X and Klibanski A: Genetic and epigenetic mutations of tumor suppressive genes in sporadic pituitary adenoma. Mol Cell Endocrinol 386(1-2): 16-33, 2014.

38 Schmidt MK, Reincke S, Broeks A, Braaf LM, Hogervorst FB, Tollenaar RA, Johnson N, Fletcher O, Peto J, Tommiska J, Blomqvist C, Nevanlinna HA, Healey CS, Dunning AM, Pharoah PD, Easton DF, Dork T, Van't Veer LJ and Breast Cancer Association C: Do MDM2 SNP309 and TP53 R72P interact in breast cancer susceptibility? A large pooled series from the breast cancer association consortium. Cancer Res 67(19): 9584-9590, 2007.

39 Boersma BJ, Howe TM, Goodman JE, Yfantis HG, Lee DH, Chanock SJ and Ambs S: Association of breast cancer outcome with status of $p 53$ and MDM2 SNP309. J Natl Cancer Inst 98(13): 911-919, 2006.

40 Hirata H, Hinoda Y, Kikuno N, Kawamoto K, Suehiro Y, Tanaka $\mathrm{Y}$ and Dahiya R: MDM2 SNP309 polymorphism as risk factor for susceptibility and poor prognosis in renal cell carcinoma. Clin Cancer Res 13(14): 4123-4129, 2007.

41 Hori Y, Miyabe K, Yoshida M, Nakazawa T, Hayashi K, Naitoh I, Shimizu S, Kondo H, Nishi Y, Umemura S, Kato A, Ohara H, Inagaki $\mathrm{H}$ and Joh T: Impact of TP53 codon 72 and MDM2 SNP 309 polymorphisms in pancreatic ductal adenocarcinoma. PLoS One 10(3): e0118829, 2015.

42 Chua HW, Ng D, Choo S, Lum SS, Li H, Soh LY, Sabapathy K and Seow A: Effect of MDM2 SNP309 and p53 codon 72 polymorphisms on lung cancer risk and survival among nonsmoking Chinese women in Singapore. BMC Cancer 10: 88, 2010.

43 Lum SS, Chua HW, Li H, Li WF, Rao N, Wei J, Shao Z and Sabapathy K: MDM2 SNP309 G allele increases risk but the T allele is associated with earlier onset age of sporadic breast cancers in the Chinese population. Carcinogenesis 29(4): 754$761,2008$.

Received January 17, 2017

Revised February 28, 2017

Accepted March 1, 2017 